\title{
Root growth and antioxidant enzyme responses to aluminium stress in sugarcane
}

\section{Crescimento radicular e resposta de enzimas antioxidantes ao estresse por alumínio em cana-de-açúcar}

\author{
Lucas Smith Pimenta ${ }^{1}$; Eduardo Dal'Ava Mariano²; Rodrigo Gazaffi; \\ Monalisa Sampaio Carneiro ${ }^{3 *}$
}

\author{
Highlights: \\ A controlled environment is an option to evaluate Al-tolerance in sugarcane. \\ Rapid and simple method to screen Al-tolerance in sugarcane cultivars \\ Antioxidant enzymes were not suitable for evaluating Al-tolerance in sugarcane.
}

\begin{abstract}
Aluminium ( $\mathrm{Al})$ toxicity in acid soils is a major abiotic stress that can limit plant production worldwide. Al toxicity directly inhibits root development and exacerbates oxidative stress in the plant. Sugarcane is mostly cultivated in tropical regions and is often exposed to phytotoxic concentrations of soil Al. In this study, our objectives were to evaluate nine sugarcane cultivars on their tolerance to $\mathrm{Al}$ in a hydroponic system, investigating the effects of $143 \mu \mathrm{M}\left\{\mathrm{Al}^{3+}\right\}$ on root growth and on activity of the antioxidant enzymes ascorbate peroxidase (APX), catalase (CAT) and superoxide dismutase (SOD). The screening method proposed was suitable for a rapid, reliable and reproducible procedure of the sugarcane cultivars. Exposure to $\mathrm{Al}$ for three days altered root growth and activity of enzymes of the nine sugarcane cultivars. However, the magnitude of the alterations varied significantly among cultivars. The cultivar RB928064 was classified as Al-tolerant and the cultivar RB835486 as Al-sensitive. Increases in enzyme activity after $\mathrm{Al}$ exposure varied from 4 to $46 \%$, with average increases of $19 \%$ in APX, $20 \%$ in CAT, and $8 \%$ in SOD. The variations induced by $\mathrm{Al}$ in enzyme activity, however, did not correlate significantly with those variations induced by $\mathrm{Al}$ in the root growth.
\end{abstract}

Key words: Toxic aluminium. ROS. Hydroponic system. Saccharum spp. Screening method.

\section{Resumo}

A toxidez por alumínio (Al) em solos ácidos é um dos principais estresses abióticos que podem limitar a produção vegetal pelo mundo todo. A toxidez por $\mathrm{Al}$ inibe diretamente o desenvolvimento radicular $\mathrm{e}$ aumenta a produção de espécies reativas de oxigênio na planta. A cana-de-açúcar é mais cultivada em regiões tropicais e frequentemente está exposta a concentrações fitotóxicas de Al no solo. Neste estudo, nossos objetivos foram avaliar a tolerância ao $\mathrm{Al}$ de nove cultivares de cana-de-açúcar em um sistema

1 Discente do Curso de Mestrado do Programa de Pós-Graduação em Produção Vegetal e Bioprocessos Associados, Centro de Ciências Agrárias, Universidade Federal de São Carlos, UFSCar, Araras, SP, Brasil. E-mail: lucassmithpimenta@gmail.com

2 Prof. Dr., Programa de Pós-Graduação em Produção Vegetal e Bioprocessos Associados, Centro de Ciências Agrárias, Departamento de Desenvolvimento Rural, UFSCar, Araras, SP, Brasil. E-mail: edmariano@ufscar.br

3 Profs. Drs., Programa de Pós-Graduação em Produção Vegetal e Bioprocessos Associados, Centro de Ciências Agrárias, Departamento de Biotecnologia e Produção Vegetal e Animal, UFSCar, Araras, SP, Brasil. E-mail: rgazaffi@ufscar.br; monalisa@ ufscar.br

* Author for correspondence 
hidropônico e investigar os efeitos de $143 \mu \mathrm{M}\left\{\mathrm{Al}^{3+}\right\}$ sobre o crescimento radicular e a atividade das enzimas antioxidantes ascorbato peroxidase (APX), catalase (CAT) e superóxido dismutase (SOD). O método de triagem proposto foi adequado para a avaliação de tolerância ao Al de forma rápida, confiável e reprodutível. A exposição ao $\mathrm{Al}$ por três dias alterou o crescimento radicular e a atividade das enzimas nas nove cultivares de cana-de-açúcar. Entretanto, a magnitude das alterações variou significativamente entre as cultivares. A cultivar RB928064 foi classificada como tolerante e a cultivar RB835486 como sensível ao Al. Os incrementos de atividade enzimática após exposição ao Al variaram entre 4 e 46\%, com incrementos médios de 19\% para APX, 20\% para CAT, e $8 \%$ para SOD. As variações induzidas pelo Al sobre a atividade enzimática, entretanto, não apresentaram correlações significativas com aquelas induzidas pelo $\mathrm{Al}$ sobre o crescimento radicular.

Palavras-chave: Alumínio tóxico. ROS. Sistema hidropônico. Saccharum spp. Método de triagem.

Sugarcane (Saccharum spp.) is a vegetatively propagated and semi-perennial crop that has been cultivated in tropical and subtropical areas of the world for centuries, mostly on acid soils $(\mathrm{pH}<5.0)$ and very often exposed to aluminium (Al) toxicity (Kochian, Piñeros, Liu, \& Magalhães, 2015; Watt, 2003; Hetherington, Asher, \& Blamey, 1986). It is estimated that about $50 \%$ of the world's potentially arable land is acid, $60 \%$ of which are in countries of the tropical and subtropical regions (Kochian et al., 2015). Soil acidity enhances solubilization of Alcontaining soil minerals, releasing into soil solution great amounts of $\mathrm{Al}$ in toxic forms such as the monomeric trivalent ion $\mathrm{Al}^{3+}$ (Singh et al., 2017).

The primary symptom caused by $\mathrm{Al}^{3+}$ is the inhibition of cell division and elongation in the root apices, causing reduced root growth, which can be more or less prominent depending on plant species and/or genotype (Ferreira, Moreira, \& Rassini, 2006; Kochian et al., 2015). A secondary effect is the impairment of plant nutrition, related to the underdeveloped root system, and a consequent decrease in biomass production. $\mathrm{Al}^{3+}$ is a powerful prooxidant, which affects the cell wall, plasma membranes and cytoskeleton, causing imbalances between production and elimination of reactive oxygen species (ROS) (Singh et al., 2017; Cia, Guimarães, Medici, Chabregas, \& Azevedo, 2012), such as superoxide $\left(\mathrm{O}_{2}^{-\bullet}\right)$, hydrogen peroxide $\left(\mathrm{H}_{2} \mathrm{O}_{2}\right)$ and hydroxyl $\left(\mathrm{OH}^{\bullet}\right) . \mathrm{Al}^{3+}$ can act either in the oxidation of membranes, generating free radicals, or enhancing up to three times the oxidative power of the superoxide radical (Kochian et al., 2015). To avoid oxidative damage by these ROS, plants can produce more antioxidant enzymes such as ascorbate peroxidase (APX), catalase (CAT) and superoxide dismutase (SOD) (Noctor, Reichheld, \& Foyer, 2018; Singh et al., 2017).

Cia et al. (2012) compared two drought-tolerant and two drought-sensitive sugarcane cultivars and observed variations in enzyme activities, including APX, CAT and SOD, according to genotype and stress intensity. Transcriptomic analyses of plants under Al stress demonstrated significant changes in the expression of genes related to metal dependent biochemical pathways, particularly on $\mathrm{Fe}^{2+} / \mathrm{Fe}^{3+}$ and $\mathrm{Mg}^{2+}$ (Exley, 2009; Kumari, Taylor, \& Deyholos, 2008).

Compared to plant species more often studied for Al-tolerance (e.g. maize, rice, wheat) the sugarcane root system has some peculiarities, which are well described in the work by Smith, Inman-Bamber and Thorburn (2005). Because sugarcane has two types of roots, with different functions, due to vegetative propagation, and high morphological variation among cultivars (Smith et al., 2005), there is a need for a specific methodology for studying sugarcane roots, especially in experiments involving Altolerance. Root growth indexes based on total root length demand certain structure (high resolution cameras, computers and softwares) and time for data analyses, while those based on seminal root length, usually adopted for plant species with a 
main seminal root, like sorghum and maize, are not appropriate for the complex sugarcane root system. Those characteristics justify our proposal of a different methodology, which is as simple as measuring seminal roots and might be as informative as total root length.

Increasing knowledge on the Al-tolerance of sugarcane cultivars, as well as on the biochemical and physiological processes involved in Al-tolerance and Al toxicity, might contribute substantially to the development of cultivars with improved performance in acid soils with toxic Al, similarly to what has been done with other crop species. Studying and screening sugarcane germplasm under environmentally controlled conditions might be an option, since these studies are rapid, inexpensive, reproducible, and their results generally agree well with those obtained at field conditions.

To address the biological specificity of the sugarcane root system, the following procedure was adopted: i) production of plantlets using setts of a standardized length of $4.5 \mathrm{~cm}$, from the central part of the stalks and from plants of the same age in the field; ii) removal of the sett roots before acclimatization in nutrient solution, which produced a more homogeneous system with only shoot roots and facilitated the manipulation of the plants during the experiments; iii) labelling of three shoot roots with plastic tape to enable their rapid and accurate identification and measurement; iv) adoption of the relative root growth (RRG) index, calculated from root growth (RG), which takes into account the root initial length and reduces data variation related to initial vigour (Famoso et al., 2010); and v) measurement of three shoot roots instead of only the longest root, to increase the number of roots sampled and thus decrease variation.

Nine sugarcane cultivars (RB835486, RB855156, RB855453, RB855536, RB867515, RB92579, RB928064, RB985476 and SP803280) were selected for the present study from the Brazilian diversity panel of sugarcane (Saccharum spp.) genotypes. They were chosen because they are widely cultivated in Brazil and very often in soils with high concentrations of $\mathrm{Al}^{3+}$. Sugarcane setts (entire transverse nodal $4.5 \mathrm{~cm}$-long sections, bearing a single intact axillary bud) were collected from the central portion of the stalks of sugarcane plants grown in field and planted individually in $180 \mathrm{~mL}$ plastic cups filled with solid substrate Plantmax $^{\circledR}$ (São Paulo, Brazil). They were kept in a greenhouse for 60 days at temperatures varying between 24 and $32^{\circ} \mathrm{C}$ with three daily irrigations of $00 \mathrm{~h} 30$ each. After this period, the sugarcane plantlets were removed from the cups and their roots were cleaned with tap water to remove the solid substrate, followed by several cleaning steps using distilled water.

Twenty plantlets of each cultivar were selected based on uniformity of root system and aerial part. The plantlets had their sett roots excised with scissors and were randomly distributed on 10 black plastic $25 \mathrm{~L}$ containers that were used throughout the experiments. Each container received two plantlets of each cultivar, 18 plantlets in total, and $20 \mathrm{~L}$ of a complete nutrient solution, of $\mathrm{pH} 4.0$ and the following composition in macro and micronutrients (mg L-1): $140 \mathrm{~N}\left(70\right.$ as $\mathrm{NO}_{3}^{-}: 70$ as $\left.\mathrm{NH}_{4}^{+}\right), 31 \mathrm{P}$, $98 \mathrm{~K}, 60 \mathrm{Ca}, 15 \mathrm{Mg}, 20 \mathrm{~S}, 0.5 \mathrm{~B}, 0.02 \mathrm{Cu}, 5 \mathrm{Fe}$ (as Fe-EDTA), $0.5 \mathrm{Mn}, 0.01 \mathrm{Mo}$, and $0.05 \mathrm{Zn}$. The containers with the plantlets were placed and maintained for seven days in a greenhouse for plant acclimatization, with temperature varying between 24 and $32^{\circ} \mathrm{C}$. In this period, the nutrient solution was continuously aerated and had its $\mathrm{pH}$ and temperature measured three times a day. When needed, the $\mathrm{pH}$ was adjusted to 4.0 with the use of solutions of $1.0 \mathrm{M} \mathrm{HCl}$ or $1.0 \mathrm{M} \mathrm{NaOH}$.

At the end of the acclimatization period, the nutrient solution of every container was replaced by $20 \mathrm{~L}$ of a simple nutrient solution composed of $1 \mathrm{mM} \mathrm{CaCl}_{2}$ and either 0 or $300 \mu \mathrm{M} \mathrm{AlCl}{ }_{3} \cdot 6 \mathrm{H}_{2} \mathrm{O}$ and acidified to $\mathrm{pH} 4.0$ with $\mathrm{HCl} 1.0 \mathrm{M}$. The concentration of $300 \mu \mathrm{M} \mathrm{AlCl}_{3} \cdot 6 \mathrm{H}_{2} \mathrm{O}$ corresponded to $143 \mu \mathrm{M} \mathrm{Al}^{3+}$ activity $\left(\left\{\mathrm{Al}^{3+}\right\}\right.$ ), calculated with the 
software WinIAP (Hepperle, 2016). The $\left\{\mathrm{Al}^{3+}\right\}$ used was based on the experiments by Hetherington et al. $(1986,1988)$. In each sugarcane plantlet, three intact shoot roots were randomly labelled with plastic tape so that the measurements were made on the same roots before and after the treatments. The plantlets were cultivated for three days in simple nutrient solution, keeping control of its aeration, temperature and $\mathrm{pH}$ as indicated for the acclimatization period.

The length of the three labelled roots of each plant was measured with a ruler at the beginning and at the end of the three-day cultivation period. Root growth $(\mathrm{RG})$ was calculated as $\mathrm{RG}=$ Root Final Length - Root Initial Length, using the average growth of the three labelled roots. The relative root growth (RRG) of each plantlet in the $143 \mu \mathrm{M}\left\{\mathrm{Al}^{3+}\right\}$ treatment was calculated by dividing its $\mathrm{RG}$ by the average RG of that same cultivar under $0 \mu \mathrm{M}\left\{\mathrm{Al}^{3+}\right\}$ treatment (Famoso et al., 2010).

After the root measurements, root apices 3.0 $\mathrm{cm}$ in length were collected from the plantlets. The roots of the two plants of the same cultivar and in the same container were cut, put together in cryogenic tubes, immediately frozen in liquid nitrogen to stop enzyme activity, and subsequently stored at $-80^{\circ} \mathrm{C}$ until analysis. Root apices samples of $1.0 \mathrm{~g}$ were macerated with a cold mortar and pestle using liquid nitrogen. Total soluble proteins were extracted from these macerated samples homogenized in 2 $\mathrm{mL}$ of a $100 \mathrm{mM}$ potassium phosphate buffer $(\mathrm{pH}$ 7.5) with $1 \mathrm{mM}$ ethylenediamine tetraacetic acid (EDTA), $3 \mathrm{mM}$ dithiothreitol (DTT) and 4\% ( $\left.\mathrm{w} \mathrm{v}^{-1}\right)$ polyvinylpolypyrrolidone (PVPP). The homogenate was centrifuged at $10,000 \mathrm{~g}$ for $30 \mathrm{~min}$ at $4^{\circ} \mathrm{C}$ and the supernatant was collected, divided into four aliquots of $200 \mu \mathrm{L}$ each, and stored at $-80^{\circ} \mathrm{C}$ until analysis (Azevedo, Alas, Smith, \& Lea, 1998).

To determine the antioxidant enzyme activity, both APX and CAT activities were measured by calculating the decomposition of $\mathrm{H}_{2} \mathrm{O}_{2}$ per time and per weight of protein. APX activity (nmol $\mathrm{H}_{2} \mathrm{O}_{2} \mathrm{~min}^{-1} \mathrm{mg}^{-1}$ protein) was assayed according to Moldes, Medici, Abrahão, Tsai and Azevedo (2008) and CAT activity (umol $\mathrm{H}_{2} \mathrm{O}_{2} \mathrm{~min}^{-1} \mathrm{mg}^{-1}$ protein) according to Azevedo et al. (1998). SOD activity was assayed by noting the ability to photochemically inhibit nitro blue tetrazolium (Giannopolitis, \& Ries, 1977). SOD activity is expressed as unity (U) of SOD per mg of protein, with 1 U SOD being equivalent to the amount of enzyme necessary to inhibit the NBT photoreduction by $50 \%$. Total protein was determined according to the method of Bradford (1976) using bovine serum albumin as standard.

The experiment followed a randomized blocks design with ten replicates for RG and RRG, and five replicates for the antioxidant enzymes activities (APX, CAT and SOD). The RG and RRG of the cultivars in each Al-treatment were compared by means of Tukey's test $(p \leq 0.05)$, while the antioxidant enzymes activities (APX, CAT and SOD) were compared using Scott-Knott's test ( $p \leq 0.05)$. Pearson correlation between RRG and fold changes in activity of each antioxidant enzyme was calculated. The statistical analyses were performed using the software R (R Development Core Team [R], 2011).

In our experiment we could observe that the sugarcane cultivars studied held considerable variation in the number and length of shoot roots, as predicted in the literature (Smith et al., 2005). The hydroponic system employed in this work was adequate for growing the sugarcane cultivars, sustaining plant vigour during the acclimatization period and allowing us to carefully evaluate the shoot root growth pattern of the cultivars under $\mathrm{Al}$ stress without the nutritional and $\mathrm{Al}^{3+}$ complexation biases. Results of the root growth measurements (RG, RRG) of the cultivars in 0 and $143 \mu \mathrm{M}\left\{\mathrm{Al}^{3+}\right\}$ treatments are presented in Table 1. 
Table 1

Root growth $\left(\mathrm{RG}=\right.$ Root Final Length - Root Initial Length) $(\mathrm{cm})$ and relative root growth $\left(R R G=R G_{A} /\right.$ $\mathrm{RGc}_{\text {ontrol }}$ ) of the sugarcane cultivars after three days in the hydroponic system with either $0 \mu \mathrm{M}\left\{\mathrm{Al}^{3+}\right\}$ or 143 $\mu \mathrm{M}\left\{\mathrm{Al}^{3+}\right\}$.

\begin{tabular}{lcc}
\hline Cultivar & $\mathrm{RG}(\mathrm{cm})\left(0 \mu \mathrm{M}\left\{\mathrm{Al}^{3+}\right\}\right)$ & $\mathrm{RRG}\left(143 \mu \mathrm{M}\left\{\mathrm{Al}^{3+}\right\}\right)$ \\
\hline RB928064 & $4.06 \mathrm{abc}$ & $1.23 \mathrm{a}$ \\
RB92579 & $3.97 \mathrm{abc}$ & $0.99 \mathrm{ab}$ \\
RB855156 & $2.75 \mathrm{c}$ & $0.99 \mathrm{ab}$ \\
RB867515 & $4.71 \mathrm{ab}$ & $0.99 \mathrm{ab}$ \\
SP80-3280 & $2.84 \mathrm{c}$ & $0.98 \mathrm{ab}$ \\
RB985476 & $5.19 \mathrm{a}$ & $0.93 \mathrm{ab}$ \\
RB855453 & $2.63 \mathrm{c}$ & $0.92 \mathrm{ab}$ \\
RB855536 & $4.10 \mathrm{abc}$ & $0.85 \mathrm{ab}$ \\
RB835486 & $3.91 \mathrm{abc}$ & $0.76 \mathrm{~b}$ \\
\hline CV $(\%)$ & 37.0 & 23.0 \\
\hline
\end{tabular}

Values are means of 10 replicates. Analyses were performed using ANOVA and Tukey's test $(p \leq 0.05)$. Different letters within each column indicate significant statistical difference between the means, according to the Tukey's test $(p \leq 0.05)$.

The coefficient of variation (CV) was $37 \%$ for the RG (at $0 \mu \mathrm{M}\left\{\mathrm{Al}^{3+}\right\}$ ) and $23 \%$ for the RRG (at $\left.143 \mu \mathrm{M}\left\{\mathrm{Al}^{3+}\right\}\right)$. Due to the high natural variability of the root characteristics studied, the CVs obtained were considered satisfactory (Caniato et al., 2007; Famoso et al., 2010; Rahim et al., 2019). Also, the statistical analysis indicated significant variation for RG $(p \leq 0.05)$ among the nine sugarcane cultivars (Table 1), reaffirming the genetic related variability of this root trait, since this evaluation did not involve any stress to the plants.

Most of the cultivars studied did not undergo great reductions of root growth under Al stress, which might indicate those cultivars have a high degree of Al-tolerance (Table 1). Thus, in order to properly discuss the Al-tolerance, we focused on the cultivars where the $143 \mu \mathrm{M}\left\{\mathrm{Al}^{3+}\right\}$ treatment produced a clear statistical distinction on RRG (Table 1), being cv. RB928064 putatively Altolerant (23\% promotion in $\mathrm{RG}$ under $\mathrm{Al}$ exposure) and cv. RB835486 putatively Al-sensitive (24\% inhibition in $R G$ ).

Currently, although sugarcane is defined as a highly Al-tolerant crop, the $\mathrm{Al}^{3+}$ activity in culture solution to distinguish the cultivars is not yet clearly defined (Hetherington et al., 1988; Maia et al., 2018). Indeed, sugarcane is a crop species known to have some highly Al-tolerant cultivars which are able to grow at culture solutions with up to $249 \mu \mathrm{M}\left\{\mathrm{Al}^{3+}\right\}$, while some cultivars considered Al-sensitive present root damage at $54 \mu \mathrm{M}\left\{\mathrm{Al}^{3+}\right\}$ (Hetherington et al., 1986, 1988).

Another interesting trait observed in sugarcane is that culture solutions containing Al-concentrations that would severely inhibit root growth in most crop species (i.e. maize, wheat) (Caniato et al., 2007; Famoso et al., 2010), actually promotes root growth in some sugarcane cultivars, which was observed in the present study for the cultivar RB928064 (Table 1) and has been reported in previous studies (Hetherington et al., 1986; Maia et al., 2018).

On the other hand, Watt (2003) observed a 43\% inhibition in the root growth of a said Al-tolerant sugarcane cultivar in a culture solution with $221 \mu \mathrm{M}$ $\left\{\mathrm{Al}^{3+}\right\}$, which indicates that the criteria to determine the degree of Al-tolerance might vary according to the set of cultivars used as reference. The variations of these criteria might be associated to different soil 
characteristics in the regions were the cultivars are bred, including the availability of toxic $\mathrm{Al}$ (Famoso et al., 2010). Our study, as well as the literature cited, indicates that, despite the fact that sugarcane is already a highly Al-tolerant species, it is still possible for breeding programs to further improve this tolerance based on root traits.

There was a general increase in the activity of the three antioxidant enzymes analysed in root apices of sugarcane plantlets exposed to Al. Increases in enzyme activity varied from 4 to $46 \%$, with average increases of $19 \%$ in APX, 20\% in CAT, and $8 \%$ in SOD. Reduced activities were also observed, varying from 1 to $20 \%$ but occurred only in a few cultivars (Table 2). The treatment with $143 \mu \mathrm{M}$ $\left\{\mathrm{Al}^{3+}\right\}$ significantly increased $(p \leq 0.05)$ the activity of APX in the cvs. RB855156 and RB867515, CAT in the cvs. RB835486, RB867515 and RB928064, and SOD in the cvs. RB855453 and RB867515. Only the SOD activity of the cv. SP80-3280 was significantly decreased.

\section{Table 2}

Enzyme activities of ascorbate peroxidase (APX as nmol $\mathrm{H}_{2} \mathrm{O}_{2} \mathrm{~min}^{-1} \mathrm{mg}^{-1}$ protein), catalase $\left(\mathrm{CAT}^{\mathrm{as}} \mu \mathrm{mol} \mathrm{H}_{2} \mathrm{O}_{2}\right.$ $\mathrm{min}^{-1} \mathrm{mg}^{-1}$ protein) and superoxide dismutase (SOD as U SOD $\mathrm{mg}^{-1}$ protein) in nine sugarcane cultivars grown in a hydroponic system with either 0 or $143 \mu \mathrm{M}\left\{\mathrm{Al}^{3+}\right\}$

\begin{tabular}{|c|c|c|c|c|c|c|}
\hline \multicolumn{4}{|c|}{$0 \mu \mathrm{M}\left\{\mathrm{Al}^{3+}\right\}$} & \multicolumn{3}{|c|}{ Fold change in $143 \mu \mathrm{M}\left\{\mathrm{Al}^{3+}\right\}$} \\
\hline Cultivar & APX & CAT & SOD & APX & CAT & SOD \\
\hline RB928064 & $1213.8 \mathrm{a}$ & $48.2 \mathrm{~b}$ & $58.1 \mathrm{a}$ & 1.09 & $1.42 *$ & 1.16 \\
\hline RB92579 & $1455.8 \mathrm{a}$ & $61.4 \mathrm{~b}$ & $64.3 \mathrm{a}$ & 0.96 & 1.16 & 1.12 \\
\hline RB855156 & $1047.4 \mathrm{~b}$ & $74.6 \mathrm{a}$ & $77.1 \mathrm{a}$ & $1.42 *$ & 1.18 & 0.90 \\
\hline RB867515 & $829.7 \mathrm{~b}$ & $60.5 \mathrm{~b}$ & $60.6 \mathrm{a}$ & $1.46^{*}$ & $1.30^{*}$ & $1.25^{*}$ \\
\hline SP80-3280 & $1370.2 \mathrm{a}$ & $87.9 \mathrm{a}$ & $65.9 \mathrm{a}$ & 1.14 & 1.05 & $0.80^{*}$ \\
\hline RB985476 & $793.5 \mathrm{~b}$ & $66.8 \mathrm{~b}$ & $58.9 \mathrm{a}$ & 1.04 & 1.16 & 1.16 \\
\hline RB855453 & $1267.3 \mathrm{a}$ & $66.6 \mathrm{~b}$ & $65.5 \mathrm{a}$ & 1.23 & 1.24 & $1.20^{*}$ \\
\hline RB855536 & $991.4 \mathrm{~b}$ & $54.8 \mathrm{~b}$ & $59.8 \mathrm{a}$ & 1.14 & 0.95 & 0.99 \\
\hline RB835486 & $916.7 \mathrm{~b}$ & $59.3 \mathrm{~b}$ & $63.9 \mathrm{a}$ & 1.22 & $1.35^{*}$ & 1.16 \\
\hline CV (\%) & 19.2 & 20.1 & 15.5 & - & - & - \\
\hline
\end{tabular}

In the $0 \mu \mathrm{M}\left\{\mathrm{Al}^{3+}\right\}$ treatment columns, different letters within each column indicate significant statistical difference between the means, according to the Scott Knott test $(p \leq 0.05)$. In the $143 \mu \mathrm{M}\left\{\mathrm{Al}^{3+}\right\}$ treatment columns, values marked with * indicate significant enzyme activity alteration caused by Al.

Although there were changes in enzyme activities, and these changes varied among the sugarcane cultivars, they were not closely accompanied by the changes in the RRG, which was demonstrated by low and non-significant Pearson correlation coefficients obtained for all nine cultivars studied.

Correlation analyses were also performed between changes in RG and in enzyme activity of the cultivars with the most contrasting tolerance to $\mathrm{Al}$, RB928064 and RB835486. These analyses showed a significant $(p \leq 0.05)$ inverse correlation between RRG and CAT $(r=-0.89)$ and SOD $(r=-0.87)$ activities in the Al-sensitive cultivar RB835486. Conversely, in the Al-tolerant cultivar RB928064, positive correlations were found between the RRG and the activity of the antioxidant enzymes, even though they were not statistically significant. Based on the significant inverse correlation between RRG and the activities of CAT and SOD in the Alsensitive cultivar, we could presume that, despite the 
plant efforts to respond to the stress, the oxidative power of $\mathrm{Al}^{3+}$ supressed the capability of the plant to express enough enzymes to scavenge the ROS generated. Also, the degree of stress tolerance varies from genotype to genotype and may be explained by the overexpression or suppression of the activity of certain enzymes (Noctor et al., 2018).

Al toxicity rapidly inhibits root growth by an apoplastic mechanism, that is, binding to and reducing the cell wall plasticity and elasticity, being the symplastic activity of the antioxidant enzymes only indirectly affected through signals such as increasing ROS inside the root cells (Kochian et al., 2015). Therefore, our results indicate that, in sugarcane, the reduction of root growth and the alterations in the activity of antioxidant enzymes in root apices are both symptoms caused by Al stress, although not necessarily correlated with each other.

Although there were clear differences of Altolerance among the sugarcane cultivars studied, with the RRG varying from a $23 \%$ promotion to a 24\% inhibition (Table 1), those changes were not generally significant. The cvs. RB928064 (putative Al-tolerant) and RB835486 (putative Al-sensitive) provided the clearest contrast among all cultivars. These two cultivars are, therefore, good candidates for further study of Al-tolerance mechanisms.

Alterations of the activity of the antioxidant enzymes APX, CAT and SOD induced by Al were not generally accompanied by those alterations of the root growth, which contradicts our initial expectations that sugarcane cultivars more tolerant to Al toxicity would sustain root growth closest to normal levels and present higher antioxidant enzyme activity when exposed to $\mathrm{Al}$, in comparison to Al sensitive cultivars.

Nevertheless, the hydroponic system used was suitable for a rapid screening procedure of the sugarcane cultivars and might be used as a complementary tool in the initial stages of sugarcane breeding programs as well as in biochemical, physiological or gene expression studies of Altolerance.

\section{Acknowledgements}

The authors gratefully acknowledge Salete Aparecida Gaziola for her support in the antioxidant enzymes analyses. This study was financed in part by Coordenação de Aperfeiçoamento de Pessoal de Nível Superior - Brazil (CAPES) - Finance Code 001. This work was supported by grants from INCT-Bioetanol (Instituto Nacional de Ciência e Tecnologia do Bioetanol), and FINEP (Financiadora de Estudos e Projetos).

\section{References}

Azevedo, R. A., Alas, R. M., Smith, R. J., \& Lea, P. J. (1998). Response of antioxidant enzymes to transfer from elevated carbon dioxide to air and ozone fumigation, in the leaves and roots of wild-type and a catalase-deficient mutant of barley. Physiologia Plantarum, 104(2), 280-292. doi: 10.1034/j.13993054. 1998.1040217.x

Bradford, M. (1976). A rapid and sensitive method for the quantitation of microgram quantities of proteinutilizing the principle of protein-dye binding. Analytical Biochemistry, 72(1), 248-254. doi: 10. 1016/0003-2697(76)90527-3

Caniato, F. F., Guimarães, C. T., Schaffert, R. E., Alves, V. M. C., Kochian, L. V., Borém, A.,... Magalhães, J. V. (2007). Genetic diversity for aluminum tolerance in sorghum. Theoretical and Applied Genetics, 114(1), 863-876. doi: 10.1007/s00122-006-0485-x

Cia, M. C., Guimarães, A. C. R., Medici, L. O., Chabregas, S. M., \& Azevedo, R. A. (2012). Antioxidant responses to water deficit by drought-tolerant and -sensitive sugarcane varieties. Annals of Applied Biology, 161(3), 313-324. doi: 10.1111/j.17447348.2012.00575.x

Exley, C. (2009). Darwin, natural selection and the biological essentiality of aluminium and silicon. Trends in Biochemical Science, 34(12), 589-593. doi: 10.1016/j.tibs.2009.07.006.

Famoso, A. N., Clark, R. T., Shaff, J. E., Craft, E., McCouch, S. R., \& Kochian, L. V. (2010). Development of a novel aluminum tolerance phenotyping platform used for comparisons of cereal aluminum tolerance and investigations into rice aluminum tolerance mechanisms. Plant Physiology, 153(3), 1678-1691. doi: 10.1104/pp.110.156794 
Ferreira, R. P., Moreira, A., \& Rassini, J. B. (2006). Toxidez de alumínio em culturas anuais. São Carlos: EMBRAPA Pecuária Sudeste.

Giannopolitis, C. N., \& Ries, S. K. (1977). Superoxide dismutases: I. Occurrence in higher plants. Plant Physiology, 59(2), 309-314. doi: 10.1104/pp.59.2.309

Hepperle, D. (2016). WinIAP ${ }^{\odot}$ - Calculation of ion activities and calcite saturation index. Win32Version, 1994. Retrieved from http://science.do-mix. de

Hetherington, S. J., Asher, C. J., \& Blamey, F. P. C. (1986). Tolerance of sugarcane to Al in soil and solution culture. Proceedings of Australian Society of Sugar Cane Technologists Congress, 8(1), 63-68. Retrieved from www.assct.com.au/media/pdfs/1986_pa_ag10. pdf

Hetherington, S. J., Asher, C. J., \& Blamey, F. P. C. (1988). Comparative tolerance of sugarcane, navybean, soybean and maize to aluminium toxicity. Australian Journal of Agricultural Research, 39(2), 171-176. doi: 10.1071/ar9880171

Kochian, L. V., Piñeros, M. A., Liu, J., \& Magalhães, J. V. (2015). Plant adaptation to acid soils: the molecular basis for crop aluminum resistance. Annual Review of Plant Biology, 66(1), 571-598. doi: 10. 1146/ annurev-arplant-043014-114822

Kumari, M., Taylor, G. J., \& Deyholos, M. K. (2008). Transcriptomic responses to aluminium stress in root of Arabidopsis thaliana. Molecular Genetics and Genomics, 279(4), 339-357. doi: 10.1007/s00438007-0316-z

Maia, C., Almeida, C. F., Costa, P. M. A., Melo, J. A. G. de, Jr., Silveira, G. da, Peternelli, L. A.,... Bhering, L. L. (2018). Phenotypic plasticity of sugarcane genotypes under aluminum stress. Journal of Experimental Agriculture International, 22(3), 1-11. doi: 10.9734/JEAI/2018/40984
Moldes, C. A., Medici, L. O., Abrahão, O. S., Tsai, S. M., \& Azevedo, R. A. (2008). Biochemical responses of glyphosate resistant and susceptible soybean plants exposed to glyphosate. Acta Physiologiae Plantarum, 30(4), 469-479. doi: 10.1007/s 11738-008-0144-8

Noctor, G., Reichheld, J. P., \& Foyer, C. H. (2018). ROSrelated redox regulation and signalling in plants. Seminars in Cell \& Developmental Biology, 80(1), 3-12. doi: 10.1016/j.semcdb.2017.07.013

R Development Core Team (2011). R: A Language and environment for statistical computing. Vienna, Austria: The R Foundation for Statistical Computing. Retrieved from http://www.R-project.org

Rahim, F., Almeida, V. C., Viana, J. M. S., Ribeiro, C., Risso, L. A., \& Ribeiro, M. P. (2019). Identification of contrasting tropical popcorn inbreds for studying aluminum toxicity tolerance inheritance. Euphytica, 215(3), 47-54. doi: 10.1007/s10681-019-2372-y

Singh, S., Tripathi, D. K., Singh, S., Sharma, S., Dubey, N. K., Chauhan, D. K., \& Vaculík, M. (2017). Toxicity of aluminium on various levels of plant cells and organism: A review. Environmental and Experimental Botany, 137(2), 177-193. doi: 10.1016/j.envexpbot.2017.01.005

Smith, D. M., Inman-Bamber, N. G., \& Thorburn, P. J. (2005). Growth and function of the sugarcane root system. Field Crops Research, 92(3), 169-183. doi: 10.1016/j.fcr.2005.01.017

Watt, D. (2003). Aluminium-responsive genes in sugarcane: identification and analysis of expression under oxidative stress. Journal of Experimental Botany, 54(385), 1163-1174. doi: 10.1093/jxb/ erg 128 